\title{
Human Fibroblasts Synthesize Elevated Levels of Extracellular Matrix Proteins in Response to Interleukin 4
}

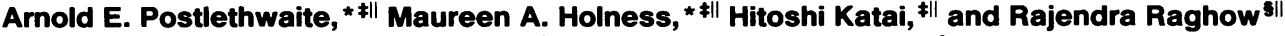 \\ ${ }^{*}$ Division of Connective Tissue Diseases, ${ }^{\ddagger}$ Department of Medicine, and ${ }^{\S}$ Department of Pharmacology, University of Tennessee, \\ Memphis, Tennessee 38163; and the "Veterans Affairs Medical Center, Memphis, Tennessee 38163
}

\begin{abstract}
Interleukin 4 (also known as "B cell stimulatory factor-1"), a cytokine product of $T$ lymphocytes and mast cells, stimulates synthesis of the extracellular matrix proteins, types I and III collagen and fibronectin, by human dermal fibroblasts in vitro. Stimulation of collagen by human recombinant (hr) IL-4 was also demonstrated in several fibroblastic synovial cell lines obtained from patients with rheumatoid arthritis and osteoarthritis. The stimulatory effect of hrIL-4 on fibroblast collagen synthesis was specifically neutralized by rabbit anti-hrIL-4 Ig. IL4 specifically increased the steady-state levels of types I and III procollagen and fibronectin mRNAs, with no effect on cytoplasmic $\beta$-actin mRNA. Quantitative analysis of the levels of Pro $\alpha 1$ (I) collagen transcripts in IL-4-treated fibroblast cultures was also corroborated by antisense RNA-mRNA hybridization and RNAse resistant hybrids which showed that IL-4treated fibroblasts expressed higher levels of Pro $\alpha 1$ (I) collagen transcripts. Nuclear run-off transcription experiments indicated that $\mathrm{IL}-4$ stimulated the rates of mRNA biogenesis. Based on these observations we conclude that IL-4 exerts its effect on collagen and fibronectin synthesis at the pretranslational level, resulting in synthesis of these extracellular matrix proteins. These and other data suggest that IL-4 may be a "fibrogenic cytokine" that could be important in promoting biogenesis of extracellular matrix proteins in normal wound healing and in pathological fibrosis in which mast cells and T lymphocytes play a central role. (J. Clin. Invest. 1992. 90:1479-1485.) Key words: collagen • fibronectin • fibrogenesis - fibrosis • wound healing
\end{abstract}

\section{Introduction}

Interleukin 4 (IL-4) is a T lymphocyte and mast cell product that was originally recognized as a factor required for DNA synthesis by resting murine $B$ cells stimulated by low concentrations of anti-Ig antibodies (1). Originally named "B cell stimulatory factor-1", it is identical to IgG1 factor, B cell growth factor- $\gamma$, mast cell growth factor- 2 , and $\mathrm{T}$ cell growth factor-2 (2-4). IL-4 stimulates IgG1 synthesis by lipopolysaccharide- and anti-Ig-stimulated B cells, enhances IgE secretion,

This work was presented in part at the Annual Meeting of the American College of Rheumatology, Cincinnati, OH, 12-17 June 1989.

Address reprint requests to Arnold E. Postlethwaite, M.D., Director, Division of Connective Tissue Diseases, University of Tennessee, Memphis, 956 Court Avenue, G326, Memphis, TN 38163.

Received for publication 4 September 1990 and in revised form 11 May 1992.

The Journal of Clinical Investigation, Inc.

Volume 90, October 1992, 1479-1485 increases class II antigen expression, and promotes growth of IL-2-dependent T cell lines (5-9). IL-4 receptors have been identified on hematopoietic cells such as normal B cells, resting and activated $\mathrm{T}$ cells, macrophages, and mast cell tumor lines (10).

Fibroblasts have receptors for IL-4 (11-12). Under some conditions, murine dermal and lung fibroblasts have been demonstrated to proliferate in the presence of murine IL-4 (13). Human fibroblasts chemotax in the presence of human recombinant $(\mathrm{hr})^{1} \mathrm{IL}-4(\mathrm{14})$. We report here that IL-4 is also capable of stimulating extracellular matrix protein biosynthesis in human dermal and synovial fibroblasts. Elevation of steady-state levels of types I and III procollagen and fibronectin mRNAs in IL-4-treated cells suggests that this cytokine regulates extracellular matrix biogenesis by pretranslational mechanisms.

\section{Methods}

Materials. Eagle's MEM, ascorbic acid, nonessential amino acids, amphotericin B, $\mathrm{NaHCO}_{3}$, penicillin, streptomycin, FCS, and PBS were purchased from Gibco Laboratories, Grand Island, NY. Radiochemicals, $\left[{ }^{35} \mathrm{~S}\right]$ methionine $\left(>1,200 \mathrm{Ci} / \mathrm{mmol}\right.$, sp act), $\left[{ }^{3} \mathrm{H}\right]$ proline ( $\mathrm{sp}$ act $20 \mathrm{Ci} / \mathrm{mmol}),\left[{ }^{32} \mathrm{P}\right] \mathrm{dCTP}($ sp act $3,000 \mathrm{Ci} / \mathrm{mmol}), \mathrm{EN}^{3} \mathrm{HANCE}$, and Aquasol were purchased from New England Nuclear, Boston, MA.

Fibroblast cultures. Primary cultures of human fibroblasts were established from explants of infant foreskins and were maintained in monolayer by standard techniques. Primary cultures of human synovial fibroblastic cells were developed from explants of synovial tissue removed from patients with $R A$ and osteoarthritis $(O A)$ at the time of surgery for joint replacement (15). Patients with OA had end stage disease requiring arthroplasty and were all receiving nonsteroidal antiinflammatory drugs (NSAIDS). The patients with RA had active disease with marked joint destruction. They were all being treated with NSAIDS and remittive agents including gold salts, azathioprine, or methotrexate. Cells were grown in 100-mm diameter petri dishes in Eagle's MEM supplemented with $9 \%$ FCS, nonessential amino acids, penicillin $(100 \mathrm{U} / \mathrm{ml})$, streptomycin $(100 \mu \mathrm{g} / \mathrm{ml})$, ascorbic acid (50 $\mu \mathrm{g} / \mathrm{ml})$, amphotericin B $(1 \mu \mathrm{g} / \mathrm{ml})$ and Earle's salts. Eagle's MEM with these supplements is hereafter referred to as "maintenance medium." Cultures were routinely passaged after trypsinization every 3-5 d.

Interleukin 4. HrIL-4 produced in yeast $(16,17)$ was purchased from Genzyme Corp., Boston, MA. The hrIL-4 preparations used were judged to be $>95 \%$ pure by silver staining of SDS-PAGE gels.

Quantitation of collagenous and noncollagenous protein synthesis. Fibroblasts were seeded $\left(5 \times 10^{4}\right.$ cells $/ 0.5 \mathrm{ml}$ maintenance medium $)$ in wells of 3424 Mark II Cluster plates (Costar Corp., Cambridge, MA) and grown for $72 \mathrm{~h}$ to reach confluency. To minimize effects of serum growth factors and factors that stimulate collagen synthesis, all cultures in which the effects of IL-4 on collagen production were measured were performed in serum-free medium as indicated. After the initial 72-h

1. Abbreviations used in this paper: hr, human recombinant; NSAIDS, nonsteroidal antiinflammatory drugs; $\mathrm{OA}$, osteoarthritis. 
culture, the medium in each well was replaced with $500 \mu \mathrm{l}$ serum-free maintenance medium containing fresh ascorbic acid $(50 \mu \mathrm{g} / \mathrm{ml}) ; 24 \mathrm{~h}$ later, medium was replaced with $450 \mu \mathrm{l}$ fresh serum-free maintenance medium (minus nonessential amino acids) containing ascorbic acid and either PBS or different concentrations of hrlL-4 in PBS (50- $\mu$ l vol each). $24 \mathrm{~h}$ later, cultures were pulsed with fresh serum-free maintenance medium (minus nonessential amino acids) containing $5.0 \mu \mathrm{Ci}$ $\left[2,3-{ }^{3} \mathrm{H}\right]$ proline ( $\mathrm{sp}$ act $20 \mathrm{Ci} / \mathrm{mmol}$ ). After a 24-h labeling period, supernatants from each well were harvested and assayed for levels of collagenase-sensitive protein as previously described (18). For SDSPAGE analysis of newly synthesized proteins, confluent fibroblast cultures (100-mm diameter petri dishes) were grown for one day in serum-free maintenance medium containing fresh ascorbic acid. Medium was then replaced with serum-free maintenance medium containing fresh ascorbic acid (minus nonessential amino acids) with or without hrIL-4 $(2.5 \mathrm{ng} / \mathrm{ml})$ for $48 \mathrm{~h}$; for the final $12 \mathrm{~h}$, cultures were pulsed with either $\left[2,3-{ }^{3} \mathrm{H}\right]$ proline $(50 \mu \mathrm{Ci} / \mathrm{ml}$, sp act $115 \mathrm{Ci} / \mathrm{mmol})$ to measure rates of collagen synthesis or $\left[{ }^{35} \mathrm{~S}\right]$ methionine $(25 \mu \mathrm{Ci} / \mathrm{ml}$, sp act $1,200 \mathrm{Ci} / \mathrm{mmol}$ ) to measure rates of total cellular protein synthesis. Polypeptides in the media and the cell layers were harvested separately and protease inhibitors (final concentration, $10 \mathrm{mM} \mathrm{N}$-ethylmaleimide, $20 \mathrm{mM}$ EDTA, and $0.3 \mathrm{mM}$ PMSF) were added. Extracellularly released polypeptides were precipitated by ethanol ( $30 \% \mathrm{vol} / \mathrm{vol})$ in the presence of $27 \mu \mathrm{g} / \mathrm{ml}$ of unlabeled bovine type I collagen as a carrier. Precipitated polypeptides were centrifuged $(10,000 \mathrm{~g}$ for 10 $\mathrm{min}$ ), and the pellet was solubilized in equal volumes of Laemmli sample buffer containing $5 \%$ 2-mercaptoethanol and heated at $100^{\circ} \mathrm{C}$ for $5 \mathrm{~min}$. Polypeptides in the samples were electrophoretically separated by $7.5 \%$ SDS-PAGE, fluorographed, and quantitated with a laser densitometer (LKB Instruments, Inc., Bromma, Sweden) coupled with an integrator (3390; Hewlett-Packard Co., Palo Alto, CA). The effects on total protein synthesis were determined by densitometry of fluorographs representing [ ${ }^{35} \mathrm{~S}$ ] methionine-labeled polypeptides (both cell associated and extracellularly released) subjected to SDS-PAGE. For quantitation, previously published protocols were used with minor modifications (19-21).

Isolation and quantitation of messenger RNAs. Confluent fibroblasts ( $72 \mathrm{~h}$ after plating) in 100-mm diameter petri dishes were treated with hrIL-4 $(2.5 \mathrm{ng} / \mathrm{ml})$. After $48 \mathrm{~h}$, total RNA was extracted by using RNAZOL (Cinna/Biotecx, Friendswood, TX). The quality and quantity of RNA were routinely tested by determining $A_{260} / A_{280}$ and ethidium bromide fluorescence of RNA electrophoresed in agarose gels. Serial dilutions of total RNA were immobilized on nitrocellulose and subjected to prehybridization and hybridization as described previously $(19,20,22)$.

Quantitation of antisense RNA-mRNA hybridization and RNAseresistant hybrids. Total RNA extracted from the control or IL-4-treated cell monolayers was hybridized to a radiolabeled antisense riboprobe. A 550-bp EcoRI-AvaI fragment removed from human Pro $\alpha 1$ (I) collagen cDNA clone HF677 (23) was cloned into the multiple cloning site of PSP6/T7-19 plasmid (24). Sense or antisense riboprobes were generated by in vitro transcription using SP6 and T7 RNA polymerase (24). Hybridization in a final vol of $30 \mu \mathrm{l}$ was carried out with the radiolabeled antisense RNA as probe $\left(3 \times 10^{5} \mathrm{cpm}\right)$ and increasing amounts $(0.5-5.0 \mu \mathrm{g})$ of total RNA isolated from human fibroblasts in hybridization buffer $\left(80 \mathrm{mM}\right.$ formamide, $40 \mathrm{mM}$ piperazine- $N, N^{\prime}-$ bis(2-ethane sulfonic acid) $\mathrm{pH} 6.4,400 \mathrm{mM} \mathrm{NaCl}, 1 \mathrm{mM}$ EDTA). RNA samples were heated to $85^{\circ} \mathrm{C}$ for $5 \mathrm{~min}$ and then incubated at $60^{\circ} \mathrm{C}$ overnight. Samples were incubated $\left(30 \mathrm{~min}\right.$ at $\left.30^{\circ} \mathrm{C}\right)$ in ribonuclease digestion buffer containing $40 \mu \mathrm{g} / \mathrm{ml} \mathrm{RNase}$ and $2 \mu \mathrm{g} / \mathrm{ml}$ RNase T1. This was followed by addition of $10 \mu \mathrm{l}$ of $20 \%$ SDS, $25 \mu \mathrm{l}$ of 20 $\mathrm{mg} / \mathrm{ml}$ proteinase $\mathrm{K}$, and then by further incubation for $15 \mathrm{~min}$ at $37^{\circ} \mathrm{C}$. Radiolabeled RNase-resistant hybrids were purified by phenol/ chloroform extraction and ethanol precipitation and were then analyzed either by denaturing polyacrylamide/urea gel or by directly counting in a scintillation spectrometer.

Nuclear run-off assays. Nuclei from control or IL-4 treated cells $\left(1-2 \times 10^{7}\right)$ were incubated in vitro in $100 \mu \mathrm{l}$ reaction mixture which contained $10 \%$ glycerol, $50 \mathrm{mM}$ Tris- $\mathrm{HCl}$, $\mathrm{pH} 8.0,5 \mathrm{mM} \mathrm{MgCl}_{2}, 1 \mathrm{mM}$ each of ATP, GTP, and CTP, and $250 \mu \mathrm{Ci}$ of $\left[\alpha^{-32} \mathrm{P}\right]$ UTP at $25^{\circ} \mathrm{C}$ for 30 min. Radiolabeled transcripts were extracted and hybridized to DNA immobilized on nitrocellulose filters. The detailed methodology for nuclear run-off assays has been described previously (19) and was used with minor modifications.

\section{Results}

Effect of hrIL-4 on collagen and fibronectin synthesis. Purified hrIL-4 stimulated production of collagen by dermal fibroblasts in a dose-dependent fashion with maximal stimulation occurring at $2.5 \mathrm{ng} / \mathrm{ml}$ (Fig. 1). Although the magnitude of the response varied with different cell lines, a similar dose-dependence to hrIL-4 was displayed by all dermal and synovial fibroblasts tested. This heterogenous response is evident in data shown in Table I wherein some dermal and synovial fibroblast lines exhibited modest increases in collagen production while others increased their production of collagen by as much as fourfold. Interestingly, hrIL-4 did not stimulate growth of confluent fibroblasts under the culture conditions used to quantitate collagen production (Table I).

The effect of hrIL-4 at doses of $2-10 \mathrm{ng} / \mathrm{ml}$ on collagen production was assessed in 82 additional dermal and 22 (13 $\mathrm{RA}$ and $9 \mathrm{OA}$ ) additional synovial fibroblast lines. $87 \%$ of the dermal fibroblast lines and $83 \%$ of the synovial fibroblast lines ( 12 of 13 RA and 6 of $9 \mathrm{OA}$ ) produced significantly increased amounts of collagen in response to hrIL-4 (data not shown). In addition, we observed that the stimulatory effect of hrIL-4 on collagen production was reproduced when the same cell lines were tested on different days (Table I), and in some cases this IL-4 responsiveness was retained in fibroblasts maintained for up to 3 mo and for 10 subpassages in culture (data not shown).

The stimulatory effect of hrIL-4 on fibroblast collagen synthesis was neutralized by pretreatment of hrIL-4 with antihrIL-4 immunoglobulin (Table II). Specificity of the antibody to block this hrIL-4-mediated response was further attested to by the fact that anti-hrIL- 4 antibody treatment of hrIL-1 did not inhibit collagen production induced by this unrelated cytokine ( Table II).

A $2.5 \mathrm{ng} / \mathrm{ml}$ dose of hrIL-4 was used in additional experiments to assess the effect of IL-4 on rates of procollagen and

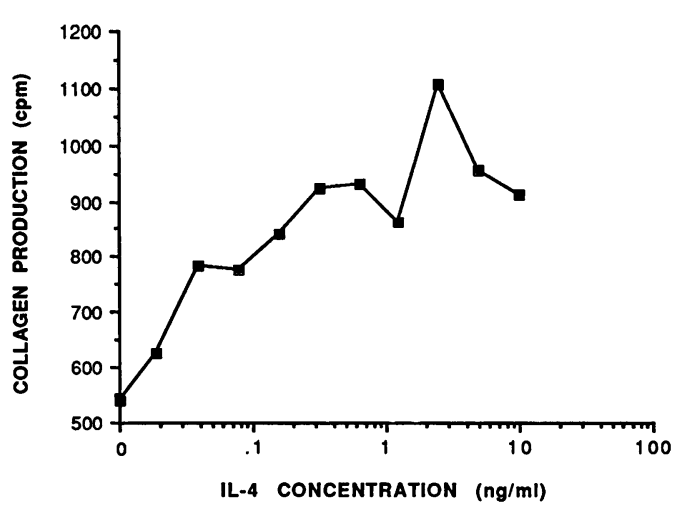

Figure 1. Effect of hrlL-4 on fibroblast collagen production. Different amounts of hrIl-4 were added to wells of multiwell plates containing confluent monolayers of dermal fibroblasts, and collagen production was quantitated by the collagenase-sensitive protein assay as described in Methods (18). 
Table I. Effect of hrIL-4 on Fibroblast Growth and Collagen Production

\begin{tabular}{|c|c|c|c|c|c|}
\hline \multirow[b]{2}{*}{$\begin{array}{c}\text { Cell line } \\
\text { and treatment }\end{array}$} & \multicolumn{3}{|c|}{ Collagen production } & \multicolumn{2}{|c|}{ Fibroblast numbers } \\
\hline & $\begin{array}{c}\text { Mean cpm } \pm \text { SEM } \\
\text { per well }\end{array}$ & Percent control & $P$ value & $\begin{array}{l}\text { Mean cells } \pm \text { SEM } \\
\text { per well }\end{array}$ & $P$ value \\
\hline \multicolumn{6}{|l|}{ Dermal fibroblasts } \\
\hline HF4 + PBS & $1,792 \pm 56$ & & & $109,000 \pm 2,600$ & \\
\hline HF4 + hrIL-4 & $4,323 \pm 43$ & 241 & $<0.001$ & $103,000 \pm 2,700$ & NS \\
\hline $\mathrm{HF} 7+\mathrm{PBS}$ & $1,089 \pm 23$ & & & $95,000 \pm 3,800$ & NS \\
\hline HF7 + hrlL-4 & $2,062 \pm 40$ & 189 & $<0.001$ & $90,000 \pm 2,600$ & \\
\hline HF8 + PBS & $1,904 \pm 66$ & & & $99,000 \pm 1,800$ & \\
\hline HF8 + hrIL-4 & $4,799 \pm 194$ & 252 & $<0.001$ & $100,000 \pm 3,600$ & NS \\
\hline HF22 + PBS & $3,122 \pm 73$ & & & & \\
\hline HF22 + hrlL-4 & $6,650 \pm 954$ & 213 & $<0.0125$ & ND & \\
\hline HF54 + PBS & $2,597 \pm 370$ & & & & \\
\hline HF54 + hrIL-4 & $5,247 \pm 158$ & 202 & $<0.01$ & ND & \\
\hline HF56 + PBS & $6,801 \pm 317$ & & & & \\
\hline HF56 + hrIL-4 & $9,336 \pm 96$ & 137 & $<0.0025$ & ND & \\
\hline HF102 + PBS & $2,201 \pm 291$ & & & & \\
\hline HF102 + hrIL-4 & $5,402 \pm 248$ & 245 & $<0.0025$ & ND & \\
\hline HF52 + PBS & $1,574 \pm 135$ & & & & \\
\hline HF52 + hrIL-4 & $2,369 \pm 155$ & 151 & $<0.01$ & ND & \\
\hline HF62 + PBS & $901 \pm 76$ & & & & \\
\hline HF62 + hrIL-4 & $2,181 \pm 195$ & 242 & $<0.0025$ & ND & \\
\hline \multicolumn{6}{|l|}{ Synovial fibroblasts } \\
\hline RA105 + PBS & $865 \pm 55$ & & & $52,000 \pm 2,300$ & \\
\hline RA105 + hrIL-4 & $1,584 \pm 43$ & 183 & $<0.001$ & $55,000 \pm 3,400$ & NS \\
\hline RA105 + PBS & $214 \pm 12$ & & & $3,000 \pm 3,000$ & \\
\hline RA105 $5^{\ddagger}+$ hrIL-4 & $587 \pm 39$ & 274 & $<0.001$ & $6,000 \pm 2,000$ & NS \\
\hline RA106 + PBS & $673 \pm 53$ & & & $59,000 \pm 4,000$ & \\
\hline RA106 + hrIL-4 & $1,610 \pm 50$ & 239 & $<0.001$ & $52,000 \pm 2,300$ & NS \\
\hline OA103 + PBS & $894 \pm 69$ & & & $73,300 \pm 6,000$ & \\
\hline OA103 + hrIL-4 & $1,112 \pm 88$ & 124 & $<0.02$ & $65,000 \pm 2,800$ & NS \\
\hline OA103* + PBS & $551 \pm 46$ & & & $73,700 \pm 1,260$ & \\
\hline OA103* + hrIL-4 & $1,238 \pm 49$ & 225 & $<0.001$ & $66,700 \pm 3,000$ & NS \\
\hline OA104 + PBS & $822 \pm 76$ & & & $61,300 \pm 4,600$ & \\
\hline OA104 + hrIL-4 & $1,459 \pm 69$ & 177 & $<0.005$ & $63,300 \pm 7,500$ & NS \\
\hline OA $104^{*}+$ PBS & $779 \pm 17$ & & & $77,900 \pm 2,700$ & \\
\hline OA104* + hrIL-4 & $1,307 \pm 96$ & 168 & $<0.005$ & $74,700 \pm 4,670$ & NS \\
\hline RA26 + PBS & $564 \pm 89$ & & & & \\
\hline RA26 + hrIL-4 ${ }^{\ddagger}$ & $2,010 \pm 73$ & 356 & $<0.005$ & ND & \\
\hline RA28 + PBS & $5,584 \pm 330$ & & & & \\
\hline RA28 + hrIL-4 ${ }^{\ddagger}$ & $8,227 \pm 993$ & 147 & $<0.025$ & ND & \\
\hline OA29 + PBS & $2,531 \pm 162$ & & & & \\
\hline OA29 + hrIL- $4^{\ddagger}$ & $11,873 \pm 149$ & 469 & $<0.0005$ & ND & \\
\hline OA19 + PBS & $145 \pm 17$ & & & & \\
\hline OA19 + hrIL- $4^{\ddagger}$ & $465 \pm 63$ & 320 & $<0.01$ & ND & \\
\hline
\end{tabular}

Infant foreskin (HF) and synovial fibroblast lines (RA and OA) were cultured in triplicate at confluency for $48 \mathrm{~h}$ in serum-free maintenance medium without nonessential amino acids with or without hrIL-4 $(2 \mathrm{ng} / \mathrm{ml})$ as described in Methods. The medium was analyzed for collagen levels by quantitating the amount of $\left[{ }^{3} \mathrm{H}\right]$ proline incorporated into collagenase-sensitive protein as described in Methods. The cell layer in each multiwell plate well was removed by trypsinization, and the number of cells in each well was quantitated by use of a hemacytometer. Statistical significance of results obtained in culture treated with hrIL-4 and PBS was determined by use of the two-sample Student's $t$ test.

* These cell lines were restudied $1-4$ wk later. ${ }^{\ddagger}$ hrIL-4 concentration $0.5 \mathrm{ng} / \mathrm{ml}$.

fibronectin synthesis by pulse labeling dermal fibroblast monolayers with either $\left[{ }^{3} \mathrm{H}\right]$ proline or $\left[{ }^{35} \mathrm{~S}\right]$ methionine. SDS-PAGE and fluorography were used to analyze the radiolabeled polypeptides. Comparative quantitative analysis of total cellular (cell associated and extracellularly released combined) and ex- tracellularly released polypeptide synthesis is shown in Fig. 2 and Table III. IL-4 had a two- to threefold stimulatory effect on the synthesis of both secreted type I procollagen and fibronectin. Although not shown here, IL-4 appeared to have similar stimulatory effect on the synthesis of both types I and III colla- 
Table II. Neutralization of hrIL-4-induced Collagen Production by Rabbit Anti-hrIL-4 Ig

\begin{tabular}{lcc} 
& \multicolumn{1}{c}{ Collagen production } & \\
\cline { 2 - 2 } Condition & Mean cpm per well \pm SEM & $P$ value \\
\hline & Experiment 1 & \\
hrIL-4 + media & $3,003 \pm 36$ & $<0.0005$ \\
Media & $1,931 \pm 46$ & \\
hrIL-4 + anti-hrIL-4 Ig & $1,676 \pm 59$ & $<0.0005$ \\
hrIL-1 $\beta$ + media & $3,198 \pm 317$ & \\
hrIL-1 $\beta$ + anti-hrIL-4 Ig & $3,036 \pm 215$ & NS \\
& & \\
& Experiment 2 & \\
hrIL-4 + media & $1,393 \pm 99$ & $<0.0005$ \\
Media & $693 \pm 46$ & \\
hrIL-4 + anti-hrIL-4 Ig & $604 \pm 53$ & $<0.0005$ \\
\hline
\end{tabular}

For experiment 1, two $250-\mu$ l aliquots each of hrIL-4 (7.5 ng) or hrlL-1 $\beta(300 \mathrm{pg})$ were separately incubated overnight at $4^{\circ} \mathrm{C}$ with either $15 \mu \mathrm{l}$ of MEM or of rabbit anti-hrIL-4 $\operatorname{Ig}(15 \mu \mathrm{g})$, and each was then added to separate triplicate wells (Mark II plates; Costar Corp.) $(2.5 \mathrm{ng} / \mathrm{ml}) \mathrm{hrIL}-4$ and $100 \mathrm{pg}$ hrIL- $1 \beta$ final concentration of confluent fibroblast monolayers for $48 \mathrm{~h}$, and collagen production was quantitated by the collagenase-sensitive protein technique as described in Methods. For experiment 2, a similar protocol was used but IL- $1 \beta$ was omitted. ${ }^{\ddagger}$ Statistical significance was assessed by use of the two-sample Student's $t$ test. For experiment 1 and experiment 2 , collagen production by media-treated fibroblasts was compared to collagen production by fibroblasts treated with hrIL-4 plus media. Collagen production by fibroblasts treated with hrIL-4 preincubated with anti-hrIL-4 Ig was compared to collagen production by fibroblasts treated with hrIL-4. Also for experiment 1, collagen production by fibroblasts treated with hrIL-1 plus media was compared to collagen production by fibroblasts treated with hrIL-1 that had been preincubated with anti-hrIL-4 Ig.

gen (our unpublished data). The effect was preferential on extracellular matrix polypeptides released in the medium since little or no change was apparent in the synthetic rates of total cellular polypeptides, labeled either with $\left[{ }^{35} \mathrm{~S}\right]$ methionine (Fig. 2 , Table III) or with $\left[{ }^{3} \mathrm{H}\right]$ proline (data not shown).

$I L-4$ effect on the steady-state accumulation of types I and III procollagen and fibronectin $m R N A s$. It was of interest to determine whether the observed increases in synthesis of collagen and fibronectin in IL-4-treated fibroblasts was reflected in the steady-state levels of their respective mRNAs. Therefore, an equal amount of total extracted RNA was size fractionated in denaturing gels and stained with ethidium bromide. RNA was then transferred onto nitrocellulose filters and probed with nick-translated cDNA plasmids specific for Pro $\alpha 1$ (I) and Pro $\alpha 1$ (III) collagens. A representative example of an ethidium bromide-stained gel and a sequential Northern analysis using Pro $\alpha 1$ (I) collagen and Pro $\alpha 1$ (III) collagen probes is shown in Fig. 3. In addition to Northern analysis, we also immobilized these samples by slot-blot hybridized to various cDNAs and quantitated the steady-state levels of various mRNAs. Densitometric analysis of the autoradiograms from these slot-blot hybridizations (Fig. 4) showed that hrIL-4 caused over a twofold increase in Pro $\alpha 1$ (I) collagen mRNA and an $\sim 40 \%$ increase in fibronectin mRNA with no effect on $\beta$-actin mRNA (Table
IV). Steady-state levels of Pro $\alpha 1$ (III) collagen mRNAs were also increased by hrIL-4, and the extent of this stimulation was similar to that observed for Pro $\alpha 1$ (I) collagen mRNAs (Fig. 3 and data not shown). The variable response to hrIL-4 from culture to culture and cell line to cell line noted in the collagenase-sensitive protein data in Table I was also apparent when steady-state levels of various mRNAs were analyzed; in another experiment, Pro $\alpha 1$ (I) collagen and Pro $\alpha 1$ (III) collagen and fibronectin mRNAs were elevated three- and fourfold without a corresponding change in $\beta$-actin mRNA (data not shown). Quantitative analysis of the levels of Pro $\alpha 1$ (I) colla-

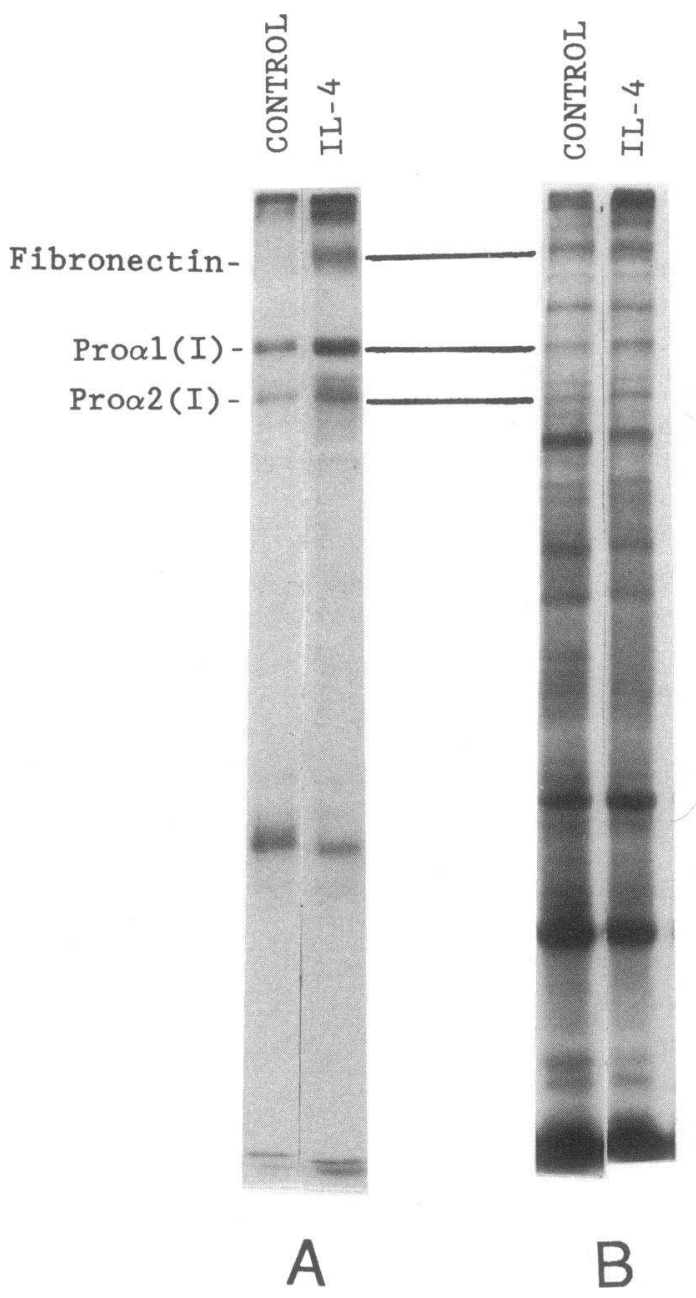

Figure 2. Analysis of radiolabeled proteins in control and hrIL-4treated fibroblasts by SDS-PAGE. Confluent dermal fibroblasts were treated for $48 \mathrm{~h}$ with $2.5 \mathrm{ng} / \mathrm{ml}$ of hrIL-4 or PBS as a control and during the final $14 \mathrm{~h}$ of culture were incubated with either $\left[{ }^{3} \mathrm{H}\right]-$ proline or $\left[{ }^{35} \mathrm{~S}\right]$ methionine as described in Methods. The extracellular protein in medium (labeled with $\left[{ }^{3} \mathrm{H}\right]$ proline) and combined extracellularly released and cell-associated proteins (labeled with $\left[{ }^{35} \mathrm{~S}\right]-$ methionine) were analyzed by $7.5 \%$ SDS-PAGE followed by fluorography. $(A)$ Extracellular proteins labeled with $\left[{ }^{3} \mathrm{H}\right]$ proline; $(B)$ total extracellular and cell-associated proteins labeled with $\left[{ }^{35} \mathrm{~S}\right]-$ methionine. The Pro $\alpha 1$ (I) and Pro $\alpha 2$ (I) collagen chains were identified by comparative migration of known procollagen chains and by their sensitivity to bacterial collagenase. The band labeled as Pro $\alpha 1$ (I) represents Pro $\alpha 1$ (I) and Pro $\alpha 1$ (III) collagen chains since both these chains comigrate under these electrophoretic conditions. Putative radiolabeled fibronectin was similarly identified by its comigration with purified human fibronectin in these gels (data not shown). 
Table III. Quantitation of Total Versus Extracellular Matrix Protein Synthesis in IL-4-treated Fibroblasts

\begin{tabular}{lccc}
\hline \multicolumn{1}{c}{ Protein } & Control & IL-4 & Fold stimulation \\
\hline Pro $\alpha$ l(I) collagen* & $0.946 \pm 0.354$ & $1.858 \pm 0.646$ & 1.96 \\
Pro $\alpha 2$ (I) collagen* & $0.541 \pm 0.227$ & $1.593 \pm 0.566$ & 2.94 \\
Fibronectin* & $0.446 \pm 0.302$ & $1.568 \pm 0.645$ & 3.52 \\
Total $^{\ddagger}$ & $9.367 \pm 0.251$ & $9.236 \pm 0.179$ & 1.00 \\
& & & \\
\hline
\end{tabular}

Confluent monolayers of fibroblasts exposed to PBS or hrIL-4 (2.5 $\mathrm{ng} / \mathrm{ml}$ ) were cultured for $48 \mathrm{~h}$. During the last $12 \mathrm{~h}$ of incubations, cultures were pulsed with either $\left[{ }^{3} \mathrm{H}\right]$ proline or $\left[{ }^{35} \mathrm{~S}\right]$ methionine and radiolabeled proteins, either cell associated or secreted in the medium, were taken up in equal volumes of Laemmli buffer and processed as described in Methods. Equal aliquots of protein extracts from control or IL-4-treated cells were analyzed by SDS-PAGE and flourographed. * Calculated from the densitometer scan of a fluorogram of $\left[{ }^{3} \mathrm{H}\right]$ proline-labeled polypeptides released into the medium and precipitated by $30 \%$ (vol/vol) ethanol. The numbers represent arbitrary densitometer units (areas of peaks integrated). Under these electrophoresis conditions Pro $\alpha 1$ (I) and Pro $\alpha 1$ (III) collagen chains comigrate, thus the effect on individual chains cannot be distinguished. ${ }^{\ddagger}$ Calculated from densitometric analysis of a fluorogram representing combined cellular and extracellularly released $\left[{ }^{35} \mathrm{~S}\right]$ methionine-labeled polypeptides.

gen transcripts in hrIL-4 $(2.5 \mathrm{ng} / \mathrm{ml})$-treated dermal fibroblast cultures was also corroborated by antisense RNA-mRNA hybridization and RNAse resistant hybrids which showed that hrIL-4-treated fibroblasts expressed higher levels of Pro $\alpha 1$ (I) collagen transcripts (Fig. 5). To investigate the level of regulation of extracellular matrix genes, nuclear run-off analysis was performed (Fig. 6); filter-immobilized DNA, representing Pro $\alpha 1$ (I) collagen, Pro $\alpha 1$ (III) collagen, and fibronectin was hybridized with radiolabeled run-off transcripts isolated from the nuclei of untreated and IL-4-treated cells. These data revealed that the rates of transcription of Pro $\alpha 1$ (I) collagen, Pro $\alpha 1$ (III) collagen, and fibronectin were preferentially increased after IL-4 treatment (Fig. 6). Densitometric quantitation of the autoradiograph obtained from nuclear run-off analysis re-

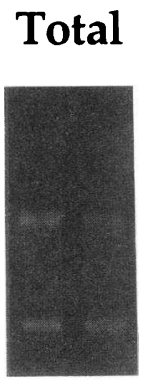

C IL-4

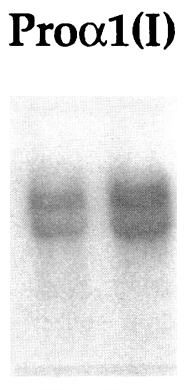

C $\quad$ IL-4
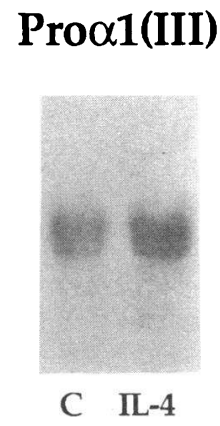

Figure 3. Effect of IL-4 on steady-state levels of Pro $\alpha 1$ (I) collagen and Pro $\alpha$ l (III) collagen mRNAs. Total cellular RNA ( $10 \mu \mathrm{g} / \mathrm{sam}$ ple) from control or IL-4-treated cells was size fractionated, stained with ethidium bromide, and transferred onto nitrocellulose. Filterimmobilized RNA was sequentially hybridized to nick-translated probes representing Pro $\alpha 1$ (I) collagen and Pro $\alpha 1$ (III) collagen cDNAs, respectively. Both Pro $\alpha 1$ (I) collagen and Pro $\alpha 1$ (III) mRNAs were increased in IL-4-treated cells.

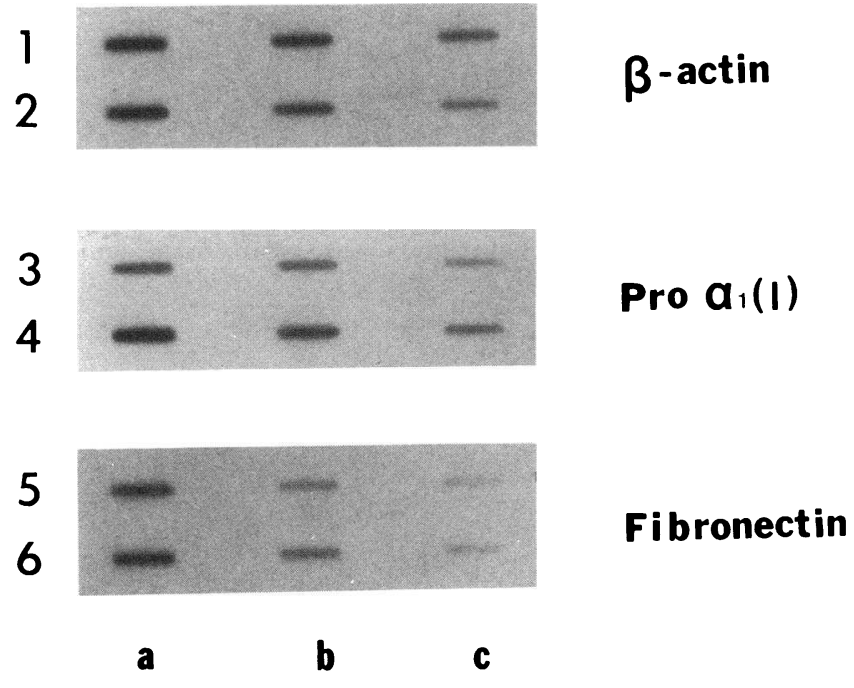

Figure 4. Effect of IL-4 on steady-state levels of mRNAs specifying $\beta$-actin, Pro $\alpha 1$ (I) collagen, and fibronectin. Total cellular RNA was isolated from control or IL-4-treated fibroblasts. $14 \mu \mathrm{g}$ (lane $a$ ), 4.6 $\mu \mathrm{g}$ (lane $b$ ), and $2.3 \mu \mathrm{g}$ (lane $c$ ) of total RNA were blotted onto nitrocellulose using a slot-blot apparatus. The membranes were then sequentially hybridized with the designated cDNA probes, dried, and autoradiographed. Lanes 1,3 , and 5 represent control samples, and lanes 2, 4, and 6 are IL-4-treated samples.

vealed about a threefold increase in the rates of transcriptions of the Pro $\alpha 1$ (I) collagen gene; transcription of Pro $\alpha 1$ (III) collagen and fibronectin genes were affected by hrIL-4 to a much lesser extent (1.8- to 2.0-fold). The nuclear run-off experiment was repeated three times and similar results were obtained (data not shown). Therefore, it would appear that the observed alterations in the rates of steady-state accumulation of various transcripts could be fully accounted for by changes in the rates of transcription after hrIL-4 treatment.

\section{Discussion}

The synthesis of the matrix components, type I and type III collagen and fibronectin, by dermal fibroblasts was stimulated

Table IV. Quantitation of Slot Blots of Specific mRNAs from Fibroblasts Treated with hrIL-4

\begin{tabular}{lccc} 
& \multicolumn{3}{c}{ Relative absorbance units } \\
\cline { 2 - 4 } \multicolumn{1}{c}{ Probe } & Control & hrIL-4-Treated & $\begin{array}{r}\text { Percentage } \\
\text { of control }\end{array}$ \\
\hline$\beta$-Actin & 5.967 & 6.226 & 104.3 \\
Pro $\alpha 1(\mathrm{I})$ collagen & 2.130 & 4.981 & 233.8 \\
Fibronectin & 2.016 & 2.895 & 143.6
\end{tabular}

Total cellular RNA was isolated from fibroblasts incubated with or without $2.5 \mathrm{ng} / \mathrm{ml} \mathrm{IL-4}$ and blotted onto nitrocellulose. Specific mRNAs were measured by hybridizing the blots with nick-translated cDNA probes representing $\beta$-actin, Pro $\alpha 1$ (I) collagen, and fibronectin. After autoradiography, the bands were quantitated by densitometry. Relative absorbance units are the sum of the areas of the three bands as shown in Fig. 4 expressed by an integrator (3390A; HewlettPackard). Results are then expressed as treated/control $\times 100$. 
by hrIL-4. Fibroblasts from the synovium of patients with RA or OA also responded to hrIL-4 with stimulation of collagen production. Highly specific anti-hrIL-4 antibodies neutralized the collagen-stimulating property of hrIL-4. Stimulation of collagen and fibronectin synthesis by IL-4 is associated with increased steady-state levels of their cognate mRNA levels resulting from enhanced rates of transcription of the target genes.

Receptors for IL-4 are present on a variety of different cell types, and it is not surprising that this $T$ cell- and mast cellderived cytokine, which was originally named B-cell stimulatory factor-1 for its ability to act as a costimulant with antiimmunoglobulins for resting B cells, is being increasingly recognized as having a plethora of activities (1-14). The effects of IL-4 on fibroblast functions may have important implications for a normal healing host response to tissue injury as well as for several human fibrosing diseases. Mast cells, which are a source of IL-4, are closely associated with inflammation and the fibrotic response ( see reference 25 for review). In normal wound healing, mast cell infiltration of the injury site parallels the accumulation of fibroblasts and matrix deposition (25). It is of interest that conditions considered to be aberrant types of wound healing (hypertrophic scars and keloids) are associated with increased numbers of mast cells in these abnormal tissues (25). There is a striking association of mast cell accumulations in fibrotic lesions of other disease states, including chronic inflammation (e.g., parasitic diseases, psoriasis, interstitial pulmonary fibrosis, and rheumatoid synovium), tumors (e.g., carcinoid, hemangiomas, neurofibromas, and mastocytosis), and scleroderma and related syndromes such as toxic oil syndrome, eosinophilic fasciitis, chronic graft-versus-host disease, and bleomycin-induced fibrosis (reviewed in 25). T cells are also intimately associated with the fibrotic response in many of these same diseases (e.g., parasitic disease, interstitial pulmonary fibrosis, rheumatoid synovium, scleroderma, and chronic graft-versus-host disease [26-29]). Serum levels of IL-4 have been reported to be elevated in patients with scleroderma (30).

The effect of IL-4 on fibroblasts is not limited to stimulation of matrix protein synthesis but also includes stimulation of growth of subconfluent fibroblasts and induction of chemotaxis of these cells $(13,14)$. The present study suggests that IL-4 should be viewed as a fibrogenic cytokine that may be

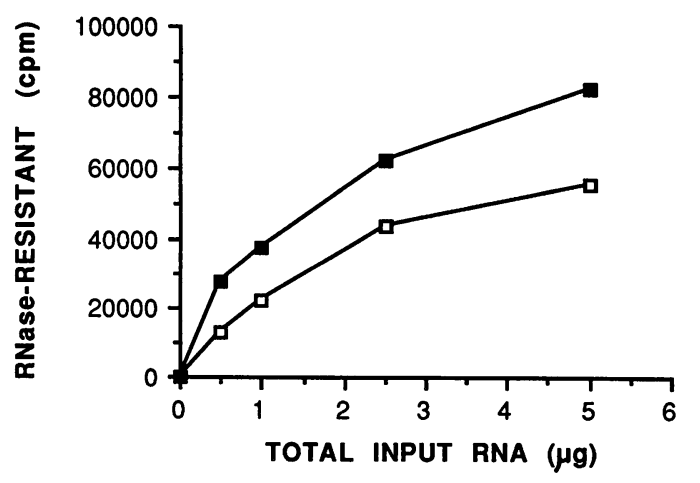

Figure 5. Determination of the steady-state rates of accumulation of Pro $\alpha 1$ (I) collagen-specific mRNA by liquid hybridization. Sense or antisense radiolabeled riboprobes were mixed with indicated amounts of total RNA extracted from either control ( $\square$ ) or hrIL-4-treated cells ( $\square$ ). Radioactivity incorporated in the double standard RNA resistant to breakdown by ribonuclease was measured by scintillation spectrometry.

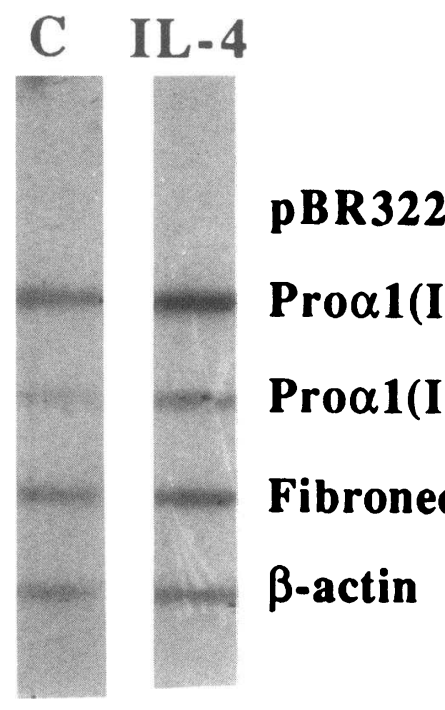

Figure 6. An autoradiogram depicting the results of a nuclear run-off transcription assay. $\mathrm{Nu}-$ clei isolated from control or hrIL-4-treated fibroblasts were incubated in an in vitro transcription run-off buffer and the radiolabeled transcripts were purified. Linearized DNA was immobilized on a nitrocellulose filter and subjected to hybridization with ${ }^{32} \mathrm{P}$-labeled transcripts as detailed previously (19). Nonspecific hybridization was determined from radioactivity bound to pBR322 DNA.

elaborated by $\mathrm{T}$ cells and/or mast cells at sites of immune and inflammatory reactions. IL-4 could then act locally to recruit fibroblasts from neighboring sites to the area where they are further stimulated to proliferate and synthesize collagen and fibronectin. IL-4 may play a significant role in directing repair processes that maintain integrity of the host in health but which may be deleterious in fibrotic diseases. The fact that synovial fibroblasts also synthesize increased amounts of collagen in the presence of IL-4 suggests that these cells could potentially elaborate increased amounts of collagen characteristic of thickened synovial membranes that accompany some forms of arthritis, perhaps in which mast cells and T cells are activated. Future studies should clarify these issues.

\section{Acknowledgments}

The authors gratefully acknowledge the excellent technical assistance of Teri Robinson, Marie Olson, and Kuldeep Patel, and the typing of this manuscript by Phyllis Mikula.

This work was supported in part by U. S. Public Health Service grants AR26034 and AR39166, and by research funds from the Department of Veterans Affairs. R. Raghow is a career scientist of the Department of Veterans Affairs.

\section{References}

1. Howard, M., J. Farrar, M. Hilfiker, B. Johnson, K. Takatsu, T. Hamaoka, and W. E. Paul. 1982. Identification of a T cell-derived B cell growth factor distinct from interleukin 2. J. Exp. Med. 155:914-923.

2. Vitetta, E. S., K. Brooks, Y.-W. Chen, P. Isakson, S. Jones, J. Layton, G. C. Mishra, E. Pure, E. Weiss, C. Ward, et al. 1984. T cell-derived lymphocytes that induce IgM and IgG secretion in activated murine B cells. Immunol. Rev. 78:137157.

3. Sideran, P., S. Bergstedt-Lindquist, and E. Severinson. 1985. Partial biochemical characterization of IgG1-inducing factor. Eur. J. Immunol. 150:593598.

4. Lee, F., T. Yokota, T. Otsuka, P. Meyerson, D. Villaret, R. Coffman, T. Mosmann, D. Rennick, N. Roehm, C. Smith, et al. 1986. Isolation and characterization of a mouse interleukin CDNA clone that expresses B-cell stimulatory factor 1 activities and T-cell and mast-cell-stimulating activities. Proc. Natl. Acad. Sci. USA. 83:2061-2066.

5. Noma, Y., P. Sideras, T. Naito, S. Bergstedt-Lindquist, C. Azuma, E. Severinson, T. Tanabe, T. Kinashi, F. Matsuda, Y. Yaoita, and T. Honjo. 1986. Cloning of $\mathrm{CDNA}$ encoding the murine IgG 1 inducing factor by a novel strategy using SP6 promoter. Nature (Lond.). 319:640-646. 
6. Isakson, P. C. 1986. Antiimmunoglobulin-treated B cells respond to a B cell differentiation factor for IgG1. J. Exp. Med. 164:303-308.

7. Coffman, R. L., J. Ohara, M. W. Bond, J. Carty, A. Zlotnik, and W. E. Paul. 1986. B cell stimulatory factor-1 enhances the IgE response of lipopolysaccharide-activated B cells. J. Immunol. 136:4538-4541.

8. Roehm, N. W., H. J. Leibson, A. Zlotnik, J. Kappler, P. Marrack, and J. C. Cambier. 1984. Interleukin-induced increase in la expression by normal mouse B cells. J. Exp. Med. 160:679-694.

9. Noelle, R., P. H. Krammer, J. W. Uhr, and E. S. Vitetta. 1984. Increased expression of Ia antigens on reacting B cells: an additional role for B-cell growth factor. Proc. Natl. Acad. Sci. USA. 811:6149-6153.

10. Ohara, J., and W. E. Paul. 1987. Receptors for B-cell stimulatory factor-1 expressed on cells of haematopoietic lineage. Nature (Lond.). 325:537-540.

11. Park, L. S., D. Friend, H. M. Sassenfeld, and D. L. Urdal. 1987. Characterization of the human B cell stimulatory factor 1 receptor. J. Exp. Med. 166:476488.

12. Lowenthal, J. W., B. E. Castle, J. Christiansen, J. Schreurs, D. Reunick, N. Arai, P. Hoy, Y. Takebe, and M. Howard. 1988. Expression of high affinity receptors for murine interleukin 4 ( BSF-1) on hemopoietic and nonhemopoietic cells. J. Immunol. 140:456-464.

13. Monroe, J. G., S. Haldar, M. B. Prystowsky, and P. Lammie. 1988. Lymphokine regulation of inflammatory processes: interleukin-4 stimulates fibroblast proliferation. Clin. Immunol. Immunopathol. 49:292-298.

14. Postlethwaite, A. E., and J. M. Seyer. 1991. Fibroblast chemotaxis induction by human recombinant interleukin-4: identification by synthetic peptide analysis of two chemotactic domains residing in amino acid sequences 70-88 and 89-122. J. Clin. Invest. 87:2147-2152.

15. Wood, D. D., E. K. Bayne, M. B. Goldring, M. Gowen, D. Hamerman, J. L. Humes, E. J. Ihrie, P. E. Lipsky, and M. J. Staruch. 1985. The four biochemically distinct species of human interleukin 1 all exhibit similar biologic activities. J. Immunol. 134:895-903.

16. Grabstein, K., J. Eisenmann, D. Mochizuki, K. Shanebeck, P. Conlon, T. Hopp, C. March, and S. Gillis. 1986. Purification to homogeneity of B cell stimulating factor. A molecule that stimulates proliferation of multiple lymphokine-dependent cell lines. J. Exp. Med. 163:1405-1414.

17. Yokota, T., T. Otsuka, T. Mosmann, J. Banchereau, T. DeFrance, D. Blanchard, J. E. DeVries, F. Lee, and K. Arai. 1986. Isolation and characterization of a human interleukin cDNA clone, homologous to mouse B-cell stimulatory factor 1, that expresses B-cell- and T-cell-stimulating activities. Proc. Natl. Acad. Sci. USA. 83:5894-5898.
18. Postlethwaite, A. E., G. N. Smith, C. L. Mainardi, J. M. Seyer, and A. H. Kang. 1984. Lymphocyte modulation of fibroblasts in vitro: stimulation and inhibition of collagen production by different effector molecules. J. Immunol. 132:2470-2477.

19. Raghow, R., D. Gossage, and A. H. Kang. 1986. Pretranslational regulation of type I procollagen, fibronectin and a 50 kilodalton noncollagenous extracellular matrix protein by dexamethasone in rat fibroblasts. J. Biol. Chem. 261:4677-4684.

20. Raghow, R., D. Gossage, J. M. Seyer, and A. H. Kang. 1984. Transcriptional regulation of type I collagen genes in cultured fibroblasts by a factor isolated from thioacetamide induced fibrotic rat liver. J. Biol. Chem. 259:1271812723.

21. Aycock, R. S., R. Raghow, G. P. Stricklin, J. M. Seyer, and A. H. Kang. 1986. Post-transcriptional inhibition of collagen and fibronectin synthesis by a synthetic homolog of a portion of the carboxyl terminal propeptide of human type I collagen. J. Biol. Chem. 261:14335-14360.

22. Thomas, P. S. 1983. Hybridization of denatured RNA transferred or dotted to nitrocellulose paper. Methods Enzymol. 100:255-266.

23. Chu, M. L., J. C. Myers, M. P. Bernard, J. F. Ding, and F. Ramirez. 1983. Cloning and characterization of five overlapping cDNAs specific for the human Pro alpha 1(I) collagen chain. Nucleic Acids Res. 10:5925-5934.

24. Melton, D. A., P. A. Krieg, M. R. Rebagliati, T. Maniatis, K. Zinn, and M. R. Green. 1984. Efficient in vitro synthesis of biologically active RNA and RNA hybridization probes from plasmids containing a bacteriophage SP6 promoter. Nucleic Acid Res. 12:7035-7056.

25. Claman, H. N. 1990. Mast cells and fibrosis. Rheum. Dis. Clin. North Am. 16:141-151.

26. Vath, R. R., C. B. Alexander, and J. D. Fulmer. 1982. The lymphocytic infiltrative lung diseases. Clin. Chest Med. 3:619-634.

27. Van Boxel, J. A., and S. A. Paget. 1975. Predominantly T cell infiltrate in rheumatoid synovial membranes. N. Engl. J. Med. 293:517-520.

28. Roumm, A. D., T. L. Whiteside, T. A. Medsger, Jr., and G. P. Rodnan 1984. Lymphocytes in the skin of patients with progressive systemic sclerosis. Quantification, subtyping, and clinical correlations. Arthritis Rheum. 6:645-653.

29. Graze, P. R., and R. P. Gale. 1979. Chronic graft versus host disease: a syndrome of disordered immunity. Am. J. Med. 66:611-620.

30. Needleman, B. W., F. M. Wigley, and R. W. Stair. 1991. Interleukin-2, interleukin-4, interleukin-6, tumor necrosis factor $\alpha$, and interferon $\gamma$ levels in sera from scleroderma patients. Arthritis Rheum. 35:67-72. 